Article

\title{
A Single V672F Substitution in the Spike Protein of Field-Isolated PEDV Promotes Cell-Cell Fusion and Replication in VeroE6 Cells
}

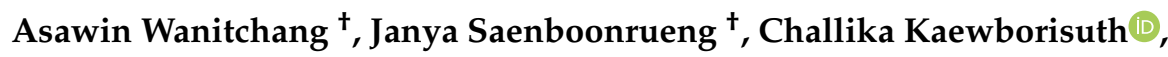 \\ Kanjana Srisutthisamphan and Anan Jongkaewwattana * (i) \\ Virology and Cell Technology Laboratory, National Center for Genetic Engineering and \\ Biotechnology (BIOTEC), National Science and Technology Development Agency (NSTDA), Pathumthani 12120, \\ Thailand; asawin.wan@biotec.or.th (A.W.); janya@biotec.or.th (J.S.); challika.kae@biotec.or.th (C.K.); \\ kanjana.sri@ncr.nstda.or.th (K.S.) \\ * Correspondence: anan.jon@biotec.or.th; Tel.: +66-2564-6700 \\ + These authors contribute equally to this work.
}

Received: 6 February 2019; Accepted: 19 March 2019; Published: 20 March 2019

check for updates

\begin{abstract}
While porcine epidemic diarrhea virus (PEDV) infects and replicates in enterocytes lining villi of neonatal piglets with high efficiency, naturally isolated variants typically grow poorly in established cell lines, unless adapted by multiple passages. Cells infected with most cell-adapted PEDVs usually displayed large syncytia, a process triggered by the spike protein (S). To identify amino acids responsible for S-mediated syncytium formation, we constructed and characterized chimeric $S$ proteins of the cell-adapted variant, YN144, in which the receptor binding domain (RBD) and S1/S2 cleavage site were replaced with those of a poorly culturable field isolate (G2). We demonstrated that the RBD, not the S1/S2 cleavage site, is critical for syncytium formation mediated by chimeric $\mathrm{S}$ proteins. Further mutational analyses revealed that a single mutation at the amino acid residue position 672 (V672F) could enable the chimeric $S$ with the entire RBD derived from the G2 strain to trigger large syncytia. Moreover, recombinant PEDV viruses bearing $S$ of the $G 2$ strain with the single V672F substitution could induce extensive syncytium formation and replicate efficiently in VeroE6 cells stably expressing porcine aminopeptidase N (VeroE6-APN). Interestingly, we also demonstrated that while the V672F mutation is critical for the syncytium formation in VeroE6-APN cells, it exerts a minimal effect in Huh-7 cells, thereby suggesting the difference in receptor preference of PEDV among host cells.
\end{abstract}

Keywords: PEDV; spike; cell-cell fusion; syncytium; chimeric proteins; receptor preference

\section{Introduction}

Porcine epidemic diarrhea virus (PEDV) causes severe enteric illness of swine (PED). The infection results in watery diarrhea, vomiting, and anorexia, which can lead to death in up to $100 \%$ of neonatal piglets [1,2]. Since its first appearance in the 1970s, PED outbreaks have caused enormous economic losses to the swine industry. Nowadays, outbreaks of PED are sporadically reported worldwide with emerging novel strains [3,4]. PEDV is an enveloped, non-segmented, positive-strand RNA virus, which constitutes the genus Alphacoronavirus of the family Coronaviridae. Its RNA genome encodes replicase proteins and structural proteins including spike (S), envelope (E), membrane (M), nucleocapsid (N), and an accessory protein (ORF3). The virus replicates efficiently in the enterocytes lining the villi of the small intestine, leading to cell death and severe villous atrophy [1].

While the replication of PEDV is thus far not completely understood, many assumptions have been made based on the data of well-characterized coronaviruses such as Severe Acute Respiratory 
Syndrome coronavirus (SARS-CoV), Middle East respiratory syndrome coronavirus (MERS-CoV), or transmissible gastroenteritis virus (TGEV). In particular, it has been shown that the structural proteins including S, M, and E proteins are gathered in the endoplasmic reticulum (ER) and transported to the endoplasmic reticulum-Golgi intermediate compartment (ERGIC), where they interact with the $\mathrm{N}$ protein-encapsidated viral genomes and assemble into viral particles followed by release via exocytosis of smooth-wall vesicles [5]. Coronavirus ( $\mathrm{CoV}$ )-infected cells typically exhibit multinucleated giant syncytia triggered by the interaction of $S$ at the cell surface and receptors of adjacent cells. $S$ has been shown to be predominantly localized in the ERGIC or Golgi complex in cells transiently expressing $S$ and $M[6,7]$. The interaction between $S$ and $M$ requires the ER retention signal (ERRS) comprising the tyrosine-dependent motif ( $\mathrm{Yxx} \phi ; \phi$ is a hydrophobic residue) and the KxHxx motif at the C-terminus of $\mathrm{S}$ [8]. However, it remains largely unknown, in the context of infection, how $\mathrm{S}$ could escape the ER-Golgi retention and transit to the plasma membrane.

In general, cells infected with cell-adapted PEDV strains usually display large syncytia. However, those infected with early passaged PEDV strains or those freshly isolated from infected intestinal tissues rarely exhibited detectable syncytium formation $[9,10]$. In the current study, we investigate the ability to trigger cell-cell fusion by $\mathrm{S}$ derived from a poorly culturable isolate, $\mathrm{G} 2$, and that from a well-characterized cell-adapted strain, YN144, in the GII genogroup [11,12]. We then constructed various chimeric $S$ constructs and evaluated cell-cell fusion in cells expressing each chimera. We could identify a key amino acid in the receptor binding domain (RBD) of $S$ that plays a critical role in syncytium formation and growth in VeroE6-APN cells. Intriguingly, we also showed that S-mediated syncytium formation in Huh-7 cells was distinct from that in VeroE6 cells. The data presented here may provide more insights into the quest for PEDV receptors among various host cells.

\section{Materials and Methods}

\subsection{Cells and Viruses}

Human embryonic kidney cells (HEK293T, ATCC CRL-3216) and African green monkey kidney cells (VeroE6, ATCC CRL-1586) were maintained in Opti-MEM (ThermoScientific, Waltham, MA, USA), and human hepatocellular carcinoma cells (Huh-7, JCRB cell bank 0403) were cultured in Dulbecco's Modified Eagle Medium (DMEM) low glucose (GE Healthcare Bio-Sciences, Pittsburg, PA, USA) at $37{ }^{\circ} \mathrm{C}$ with $5 \% \mathrm{CO}_{2}$. All culture media were supplemented with $10 \%$ fetal bovine serum and an antibiotic/mycotic (ThermoScientific). Notably, VeroE6 cells stably expressing porcine aminopeptidase $\mathrm{N}$ (VeroE6-APN) were constructed by retroviral transduction as described previously [13]. Recombinant PEDVs used in this study were propagated in VeroE6-APN or Huh-7 cells, and virus titration was performed on VeroE6-APN or Huh-7 cell monolayers. Briefly, cells were grown to confluence in six-well plates, washed twice with $1 \times$ Phosphate buffered saline (PBS), and inoculated with 10-fold serial dilutions of the recombinant PEDV. Infected cells were maintained in Opti-MEM containing recombinant trypsin $(2 \mu \mathrm{g} / \mathrm{mL})$ (ThermoScientific). At $24 \mathrm{~h}$ after infection, cells were fixed with $80 \%$ cold acetone for $10 \mathrm{~min}$, washed twice with PBS, and blocked in PBS containing $10 \%$ fetal bovine serum(FBS) and $1 \%$ bovine serum albumin (BSA) for $1 \mathrm{~h}$ with gentle agitation. Subsequently, cells were incubated with mouse anti-PEDV N antibodies (Medgene, Brookings, SD, USA) and goat anti-mouse IgG alkaline phosphatase antibodies (Abcam, Cambridge, MA, USA). The plaque forming unit (PFU) was examined based on color formation after the addition of 1-Step ${ }^{\mathrm{TM}}$ NBT/BCIP Substrate Solution (ThermoScientific).

\subsection{Plasmid Constructs}

The full-length S of PEDV $\mathrm{YN} 144_{\text {(S }}$ Y $144 ;_{\text {; }}$ GenBank KT021232.1) and PEDV $\mathrm{G}_{\mathrm{G}}\left(\mathrm{S}_{\mathrm{G} 2}\right)$ were codon optimized for high expression in mammalian cells, synthesized, and cloned in the pUC57 cloning vector (Synbio Technologies, Monmouth Junction, NJ, USA). Of note, the amino acid sequence of $\mathrm{S}_{\mathrm{G} 2}$ is not yet available in the public database, but it is more than $99 \%$ identical to the strain 13JM-291 
(GenBank ATJ03623). The synthetic gene was designed to be flanked by MluI and NotI restriction sites to facilitate the cloning into the modified pCAGGS expression plasmid. Removal of the C-terminal

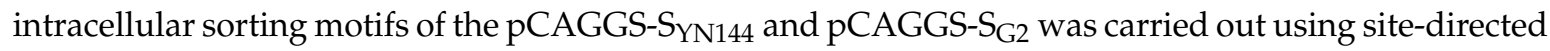
mutagenesis by adding double stop codons before $\mathrm{Yxx} \phi$ and $\mathrm{KxHxx}$ motifs at the cytoplasmic tail. Notably, to facilitate the construction of chimeric $S$, unique restriction enzyme cutting sites (NheI and SmaI) were designed to swap the fragment spanning residues 440-940 between $\mathrm{S}_{\mathrm{YN} 144}$ and $\mathrm{S}_{\mathrm{G} 2}$.

The full-length infectious clones of PEDVmCherry bearing designated $S$ constructs were generated using a strategy described previously [13]. Briefly, a cloning vector (pTZ-GH) expressing S-E-M of the prototype PEDV $\mathrm{AVCT12}_{2}$ were constructed and used as an intermediate plasmid. Each $S$ construct was introduced into the pTZ-GH by replacing the original S using In-Fusion HD Cloning (Clontech, Mountain View, CA, USA) following the manufacturer's instruction. The full-length pSMART-BAC-PEDVmCherry bearing each $S$ was then constructed by replacing the PacI-MluI fragment of the pTZ-GH with that of the infectious cDNA clone.

\subsection{Syncytium Formation Assay}

VeroE6-APN or Huh-7 cells $\left(5 \times 10^{5}\right.$ cells $\left./ \mathrm{mL}\right)$ were seeded in a six-well plate in Opti-MEM or DMEM low glucose supplemented with $10 \%$ FBS. At $24 \mathrm{~h}$, cells were washed with $1 \times$ PBS and maintained in media without FBS. Cells were transfected with pCAGGS expressing $S(1.5 \mu \mathrm{g})$ using FuGENE HD (Promega, Madison, WI, USA) according to the manufacturer's instructions. Media containing transfection mixture were removed $8 \mathrm{~h}$ post transfection $(\mathrm{hpt})$. Cells were subsequently maintained in media containing trypsin $(2 \mu \mathrm{g} / \mathrm{mL})$. At $24 \mathrm{hpt}$, cells were examined under an inverted light microscope for syncytium formation.

\subsection{Recovery of Recombinant PEDV from Infectious cDNA Clones}

HEK293T cells were grown to 90-95\% confluence and transfected with $2 \mu \mathrm{g}$ of each infectious cDNA clone construct using FuGENE HD. No trypsin was added at this step to avoid cell toxicity. At $72 \mathrm{hpt}$, supernatants were adsorbed onto the monolayer of VeroE6-APN or Huh-7 cells and cultured in Opti-MEM supplemented with trypsin $(2 \mu \mathrm{g} / \mathrm{mL})$. Cells were monitored daily for syncytium formation and mCherry expression under a fluorescence microscope. Supernatants were harvested when cytopathic effects were apparent. Virus supernatant suspensions were stored at $-80^{\circ} \mathrm{C}$.

\subsection{Immunofluorescence Assay}

VeroE6-APN cells were grown on coverslips in six-well plates and transfected with pCAGGS expressing S. At $24 \mathrm{hpt}$, cells were washed with PBS and fixed with $4 \%$ paraformaldehyde (PFA) for $20 \mathrm{~min}$ at $4{ }^{\circ} \mathrm{C}$. Cells were then washed and blocked with PBS containing $10 \% \mathrm{FBS}, 1 \%$ BSA for $1 \mathrm{~h}$ for surface staining. For intracellular staining, $0.2 \%$ TritonX-100 was also included in the blocking solution. Cells were subsequently incubated for $1 \mathrm{~h}$ with mouse anti-PEDV S1 antibodies (a kind gift from Dr. Qigai He) in 10\% FBS at a dilution of 1:500. After washing, goat anti-mouse IgG Alexa Fluor 647 (Abcam) in 10\% FBS at a dilution of 1:1000 was added and further incubated for $1 \mathrm{~h}$. The glass slips were mounted on slides with ProLong Gold Antifade Mountant with DAPI (ThermoScientific). The samples were analyzed by Fluoview ${ }^{\mathrm{TM}}$ FV1000 confocal microscopy (Olympus, Tokyo, Japan).

\subsection{Flow Cytometry}

HEK293T cells were seeded in six-well plates and transfected with pCAGGS expressing PEDV $S$ $(1.5 \mu \mathrm{g})$. At $24 \mathrm{hpt}$, cells were carefully detached, fixed with $4 \%$ PFA, and blocked in blocking buffer ( $2 \%$ FBS and $0.5 \%$ BSA in PBS) for $1 \mathrm{~h}$. Cells were then incubated with mouse anti-PEDV S1 antibodies for $1 \mathrm{~h}$. An anti-calreticulin ER marker (Abcam) was used as a non-permeabilized condition control. Cells were washed with PBS and incubated with anti-mouse Alexa Fluor 647 (IgG H + L) antibodies for $1 \mathrm{~h}$. Cells were washed and analyzed on a FlowSight ${ }^{\circledR}$ Imaging Flow Cytometer (Merck, Kenilworth, NJ, USA). 


\subsection{Western Blot Analysis}

Cells were lysed with mammalian cell lysis buffer (50 mM Tris $\mathrm{HCl} \mathrm{pH} \mathrm{8.0,100} \mathrm{mM} \mathrm{NaCl,} 2 \mathrm{mM}$ DTT, 5 mM EDTA, $0.5 \%$ NP-40, and protease inhibitors). Aliquots of whole cell lysates were separated by sodium dodecyl sulfate polyacrylamide gel electrophoresis (SDS-PAGE), and the proteins were then transferred onto nitrocellulose membranes (Bio-Rad Laboratories, Hercules, CA, USA). The membrane was blocked in $5 \%$ dry powdered milk and incubated with mouse anti-PEDV S1 or $-\beta$ actin antibodies. The membranes were then incubated with horseradish peroxidase (HRP)-conjugated goat anti-mouse IgG (1:5000; Biolegend, San Diego, CA, USA). Target proteins were visualized using Clarity Western ECL Substrate (Bio-Rad Laboratories).

\subsection{Statistical Analysis}

GraphPad Prism 7.0 (GraphPad Software Inc., La Jolla, CA, USA) was used for statistical analyses.

\section{Results}

\subsection{Distinct Cell-Cell Fusion Induced by $S_{Y N 144}$ and $S_{G 2}$ in VeroE6-APN Cells}

PEDV strain YN144 is a well-characterized cell-adapted PEDV in the GII genogroup. Not only does it replicate efficiently in mammalian cells, but it also exhibits a highly syncytial phenotype in cell culture [11,12]. While the C-terminal motifs are believed to play a key role in its ability to trigger cell-cell fusion [14-17], it is important to note that $S_{Y N 144}$ harbored no change of amino acids at the C-terminal region upon multiple passages [12]. To confirm the ability of $\mathrm{S}_{Y N 144}$ in syncytium induction, we synthesized codon-optimized $S_{Y N 144}$, cloned into the pCAGGS expression vector and evaluated the cell-cell fusion activity in transfected VeroE6-APN cells. Notably, codon-optimization is required to obtain a detectable expression of CoV S in transfected cells [18]. As depicted in Figure 1A, cells transfected with pCAGGS expressing $S_{Y N 144}$ exhibited clear syncytium formation in the presence of trypsin. Without trypsin treatment, no syncytia were observed (Figure 1A). We subsequently removed the C-terminal motifs from the $\mathrm{S}_{\mathrm{YN} 144}\left(\mathrm{~S}_{\mathrm{YN} 144} \Delta \mathrm{ERRS}\right)$ and evaluated the syncytium formation in transfected VeroE6-APN cells in the presence and absence of trypsin. The absence of the C-terminal motifs resulted in the induction of notably larger syncytium formation in transfected cells (Figure 1A). In contrast to $\mathrm{S}_{\mathrm{YN} 144}$, when we transfected VeroE6-APN cells with pCAGGS expressing $\mathrm{S}_{\mathrm{G} 2}$, we could not detect any syncytia even in the presence of trypsin or absence of the C-terminal motifs (Figure 1B). Of note, the expression level of $\mathrm{S}_{\mathrm{G} 2}$ and $\mathrm{S}_{\mathrm{YN} 144}$ were shown previously to be comparable [9], thereby suggesting that the loss of cell-cell fusion activity was not due to the difference in protein expression. These results suggest that $\mathrm{S}$ derived from the cell-adapted variant can trigger syncytium formation regardless of the C-terminal motifs, corroborating the notion that changes during serial passages may enable the $S$ protein to trigger cell-cell fusion in cultured cells. 
A.

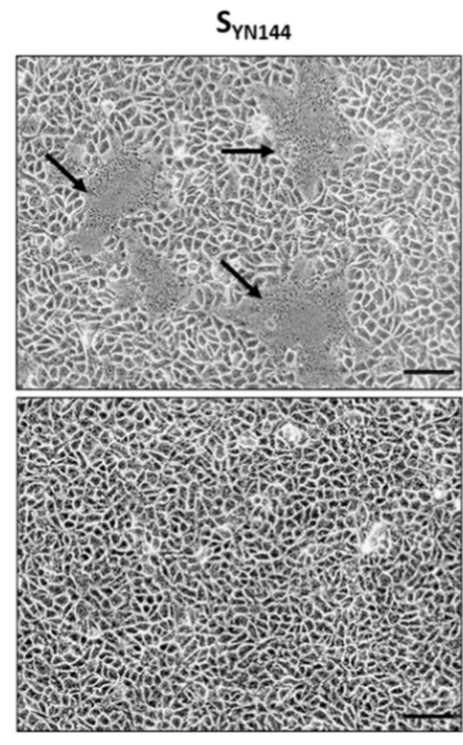

$\mathrm{S}_{\mathrm{G2}}$

B.

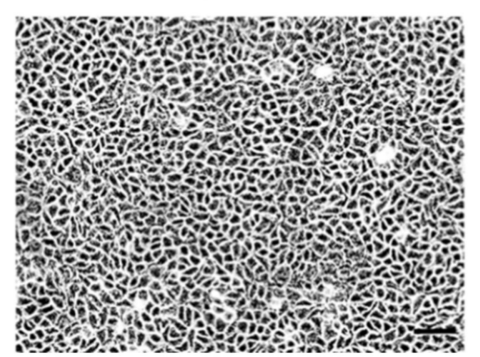

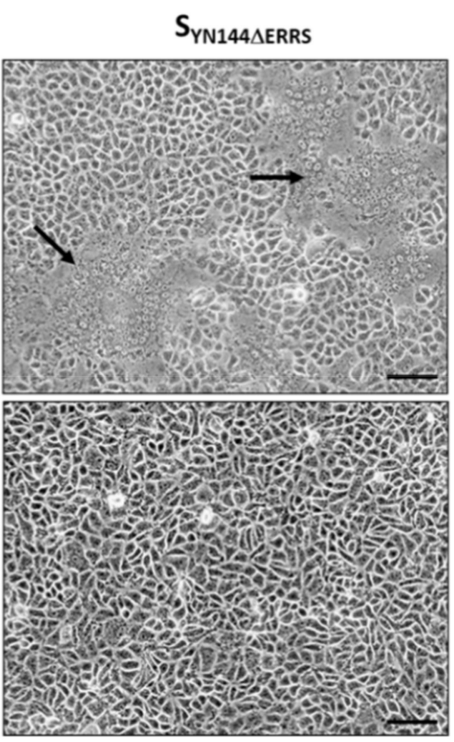

$S_{\text {GLERRS }}$

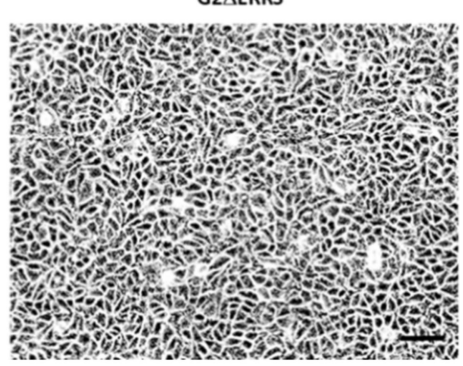

Trypsin

\section{Trypsin}

$+$

Figure 1. Formation of syncytia in VeroE6 cells stably expressing porcine aminopeptidase N (VeroE6-APN) expressing porcine epidemic diarrhea virus (PEDV) S derived from YN144 and G2. (A) VeroE6-APN cells were transfected with pCAGGS expressing SYN144 with or without the C-terminal motifs (SYN144AERRS). Cells were cultured in the presence or absence of trypsin $(2 \mu \mathrm{g} / \mathrm{mL})$. Syncytium formation was evaluated under a light microscope at $24 \mathrm{~h}$ post transfection (hpt). Arrows denote syncytium formation. Scale $100 \mu \mathrm{m}$. (B) VeroE6-APN cells were transfected with pCAGGS expressing $\mathrm{S}_{\mathrm{G} 2}$ with or without the C-terminal motifs $\left(\mathrm{S}_{\mathrm{G} 2 \Delta \mathrm{ERRS}}\right)$. Cells were cultured in the presence of trypsin $(2 \mu \mathrm{g} / \mathrm{mL})$, and the syncytium formation was assessed at $24 \mathrm{hpt}$. Scale $100 \mu \mathrm{m}$.

\section{2. $S_{G 2}$ Lacking the C-Terminal Motifs Showed Strong Cell Surface Expression}

The finding that $\mathrm{S}_{\mathrm{G} 2 \Delta \mathrm{ERRS}}$ failed to induce syncytium formation in transfected cells prompted us to speculate whether the protein expression at the cell surface, which is required for cell-cell fusion, was disturbed by this modification. To this end, we transfected VeroE6-APN cells and assessed the surface expression of $\mathrm{S}_{\mathrm{G} 2 \Delta \mathrm{ERRS}}$ by confocal microscopy. As a comparison, $\mathrm{S}_{\mathrm{YN} 144 \triangle \mathrm{ERRS}}$ was also investigated. We found that both $\mathrm{S}_{\mathrm{G} 2 \Delta \mathrm{ERRS}}$ and $\mathrm{S}_{\mathrm{YN} 144 \Delta \mathrm{ERRS}}$ displayed comparably strong surface expression (Figure 2A). Surprisingly, despite the apparent syncytium formation, the inclusion of the C-terminal motifs to $\mathrm{S}_{\mathrm{YN} 144}$ resulted in a substantial decrease in surface expression (Figure 2A). Moreover, $\mathrm{S}_{\mathrm{G} 2}$ containing the intact $\mathrm{C}$-terminal motifs $\left(\mathrm{S}_{\mathrm{G} 2}\right)$ also showed hardly detectable surface expression (Figure 2A), confirming the role of ERRS in S cellular trafficking. To further confirm the results obtained from the immunofluorescence assay (IFA), we employed flow cytometry to assess the surface expression of $\mathrm{S}_{\mathrm{G} 2 \Delta \mathrm{ERRS}}$. As expected, the absence of the C-terminal motifs could significantly augment the surface expression of both $\mathrm{S}_{\mathrm{G} 2}$ and $\mathrm{S}_{\mathrm{YN} 144}$ (Figure 2B). The fact that $\mathrm{S}_{\mathrm{G} 2 \Delta \text { ERRS }}$ showed strong surface expression but could not trigger detectable syncytium indicates that surface expression alone may not be sufficient to trigger cell-cell fusion. 
A.
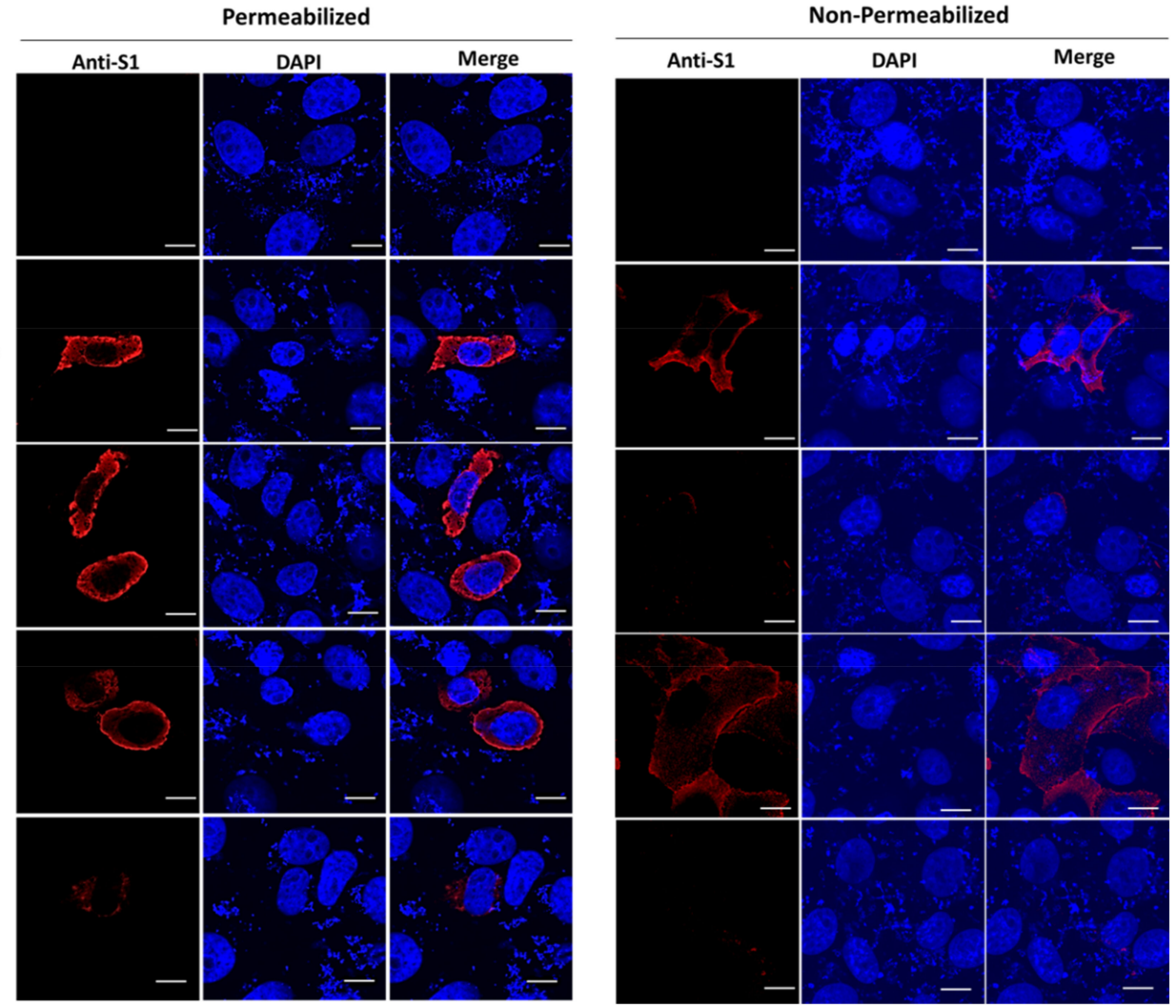

B.
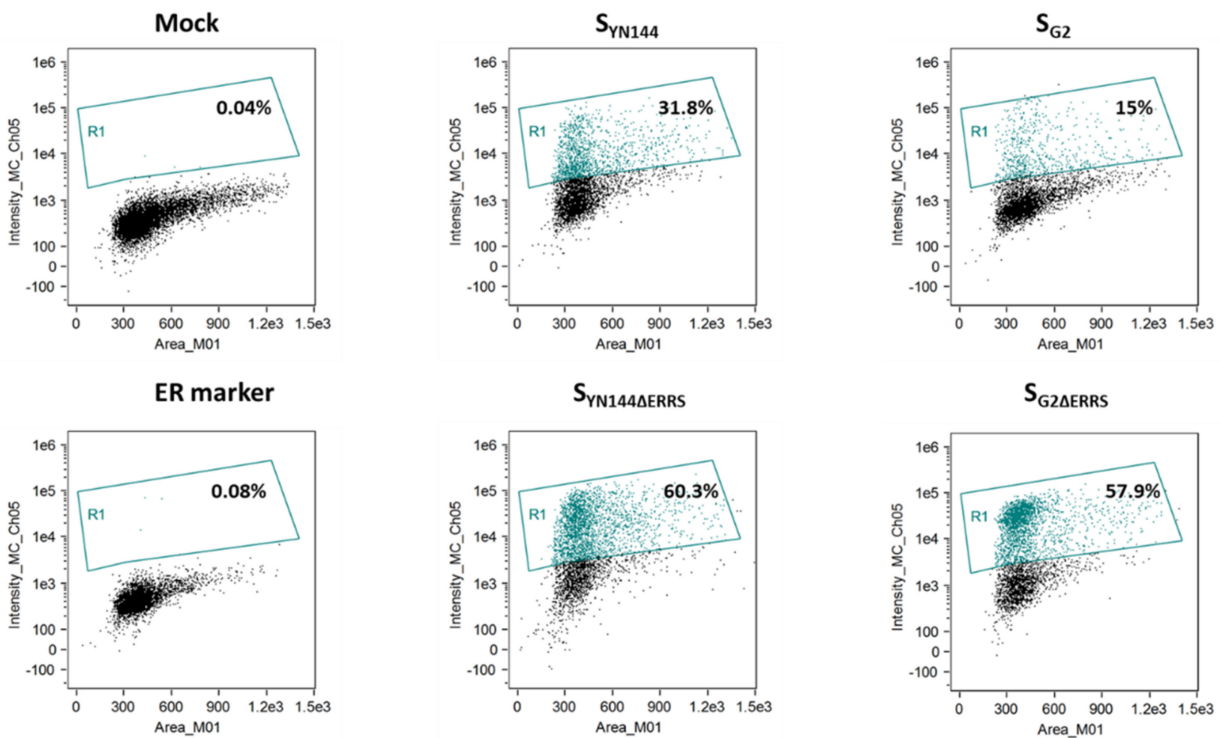

Figure 2. Surface expression of PEDV S lacking the C-terminal motifs. (A) VeroE6-APN cells were transfected with pCAGGS expressing indicated PEDV S. At $24 \mathrm{hpt}$, cells were subjected to immunofluorescence analysis under permeabilized and non-permeabilized conditions using mouse anti-PEDV S1 and goat anti-mouse IgG Alexa Fluor 647 (IgG H + L) antibodies as primary and secondary antibodies. The glass slips were mounted on slides with DAPI. The samples were analyzed by confocal microscopy. Scale $5 \mu \mathrm{m}$. (B) HEK293T cells were transfected with pCAGGS expressing indicated PEDV S. At $24 \mathrm{hpt}$, cells were detached, fixed, and incubated with mouse anti-PEDV S1 monoclonal antibodies. Cells were subsequently incubated with goat anti-mouse Alexa Fluor 647 (IgG $\mathrm{H}+\mathrm{L}$ ) antibodies and analyzed on a flow cytometer. An anti-calreticulin endoplasmic reticulum (ER) marker was used as a non-permeabilized condition control. 


\subsection{Chimeric $S_{Y N 144}$ Bearing RBD and S1/S2 Cleavage of $S_{G 2}$ Failed to Induce Syncytium Formation}

Successful syncytium formation requires not only interaction of $S$ with the receptor, but also proteolytic cleavage of $S$ to facilitate cell-cell fusion [19]. We thus sought to determine whether the $\mathrm{RBD}$ and the S1/S2 cleavage site (S1/S2) contribute to the syncytium induction activity of $\mathrm{S}_{\mathrm{G} 2}$ and $\mathrm{S}_{\mathrm{YN} 144}$. To this end, we constructed the chimeric $\mathrm{S}_{\mathrm{YN} 144}$ harboring the RBD and S1/S2 derived from $\mathrm{S}_{\mathrm{G} 2}\left(\mathrm{~S}_{\mathrm{YN}-\mathrm{G} 2}\right)$ as well as the $\mathrm{S}_{\mathrm{G} 2}$ carrying the $\mathrm{RBD}$ and $\mathrm{S} 1 / \mathrm{S} 2$ of $\mathrm{S}_{\mathrm{YN} 144}\left(\mathrm{~S}_{\mathrm{G} 2-\mathrm{YN}}\right)$ (Figure 3A). Of note, to rule out the effect of surface localization, all constructs were devoid of the C-terminal motifs. When each construct was evaluated for its ability to trigger syncytia in transfected cells, we found that while $\mathrm{S}_{\mathrm{YN} 144}$ triggered large syncytia, $\mathrm{S}_{\mathrm{YN}-\mathrm{G} 2}$ failed to do likewise, similar to that in cells transfected with $\mathrm{S}_{\mathrm{G} 2}$ (Figure 3B). In contrast, we detected clear syncytium formation, albeit relatively smaller than those of $\mathrm{S}_{\mathrm{YN} 144}$, in cells transfected with $\mathrm{S}_{\mathrm{G} 2-\mathrm{YN}}$ (Figure 3B). Notably, the absence of syncytia in cells expressing $\mathrm{S}_{\mathrm{YN}-\mathrm{G} 2}$ and $\mathrm{S}_{\mathrm{G} 2}$ was not due to a defect in protein expression, as the western blot analysis showed relatively high protein expression of all constructs (Figure 3C). Taken together, these results suggest that amino acids in the RBD and S1/S2 of PEDV S could influence S-mediated induction of cell-cell fusion in VeroE6-APN cells.

A.

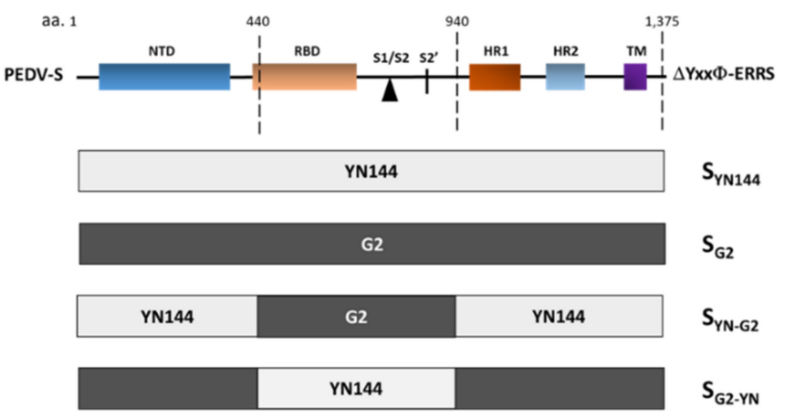

B.

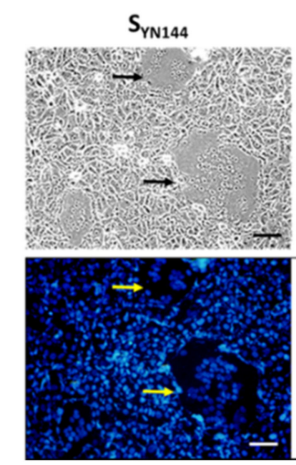

$S_{62}$
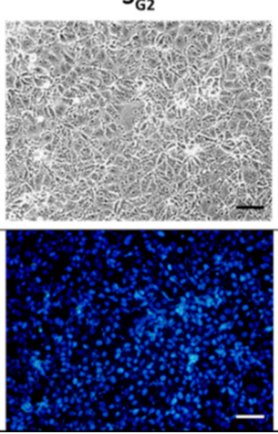

c.

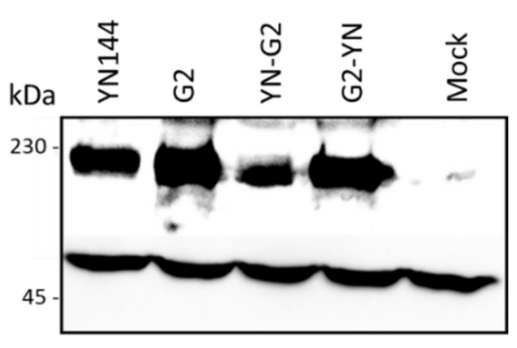

Figure 3. Syncytium formation in VeroE6-APN cells expressing chimeric $\mathrm{S}_{\mathrm{YN} 144}$ bearing receptor binding domain (RBD) and $\mathrm{S} 1 / \mathrm{S} 2$ cleavage of $\mathrm{S}_{\mathrm{G} 2}$. (A) Schematic representation of chimeric PEDV $\mathrm{S}$ in which the $\mathrm{RBD}$ and the $\mathrm{S} 1 / \mathrm{S} 2$ cleavage site of $\mathrm{S}_{\mathrm{YN} 144}$ were replaced with that of $\mathrm{S}_{\mathrm{G} 2}$ or vice versa. (B) VeroE6-APN cells were transfected with pCAGGS expressing $\mathrm{S}_{\mathrm{YN} 144}, \mathrm{~S}_{\mathrm{G} 2}$, or the chimeric $\mathrm{S}_{\mathrm{YN}-\mathrm{G} 2}$ and $\mathrm{S}_{\mathrm{G} 2-\mathrm{YN}}$ and cultured in the presence of trypsin. At $24 \mathrm{hpt}$, cells were evaluated for syncytium formation. Hoechst was used to stain nuclei. Arrows denote the formation of the syncytium. Scale $100 \mu \mathrm{m}$. (C) Western blot analysis of HEK293T cells transfected with pCAGGS expressing $\mathrm{S}_{\mathrm{YN} 144}, \mathrm{~S}_{\mathrm{G} 2}$, $\mathrm{S}_{\mathrm{YN}-\mathrm{G} 2}$, or $\mathrm{S}_{\mathrm{G} 2-\mathrm{YN}}$. Mouse anti-PEDV $\mathrm{S} 1$ and $-\beta$ actin antibodies were used to detect protein expression in cell lysates harvested $48 \mathrm{hpt}$.

\subsection{Amino Acids in the RBD Are Critical for Cell-Cell Fusion Induced by $S_{Y N 144}$}

Both $\mathrm{S}_{\mathrm{YN} 144}$ and $\mathrm{S}_{\mathrm{G} 2}$ are derived from the GIlb genogroup, and the RBD and S1/S2 between the two proteins differ by nine amino acids with four residues in the RBD and five residues in the S1/S2 (Figure 4A). We further constructed and examined the syncytium-inducing property of chimeric $S$ variants, in which RBD and S1/S2 of $\mathrm{S}_{\mathrm{YN} 144}$ were replaced with those of $\mathrm{S}_{\mathrm{G} 2}$, designated $\mathrm{S}_{\mathrm{G} 2 \mathrm{~A}}$ and 
$\mathrm{S}_{\mathrm{G} 2 \mathrm{~B}}$ (Figure 4B). As depicted in Figure 4C, we found that VeroE6-APN cells transfected with $\mathrm{S}_{\mathrm{G} 2 \mathrm{~B}}$ but not $\mathrm{S}_{\mathrm{G} 2 \mathrm{~A}}$ exhibited extensive syncytium formation, thereby suggesting that the RBD of $\mathrm{S}_{\mathrm{G} 2}$ could render $\mathrm{S}_{\mathrm{YN} 144}$ unable to induce cell-cell fusion.

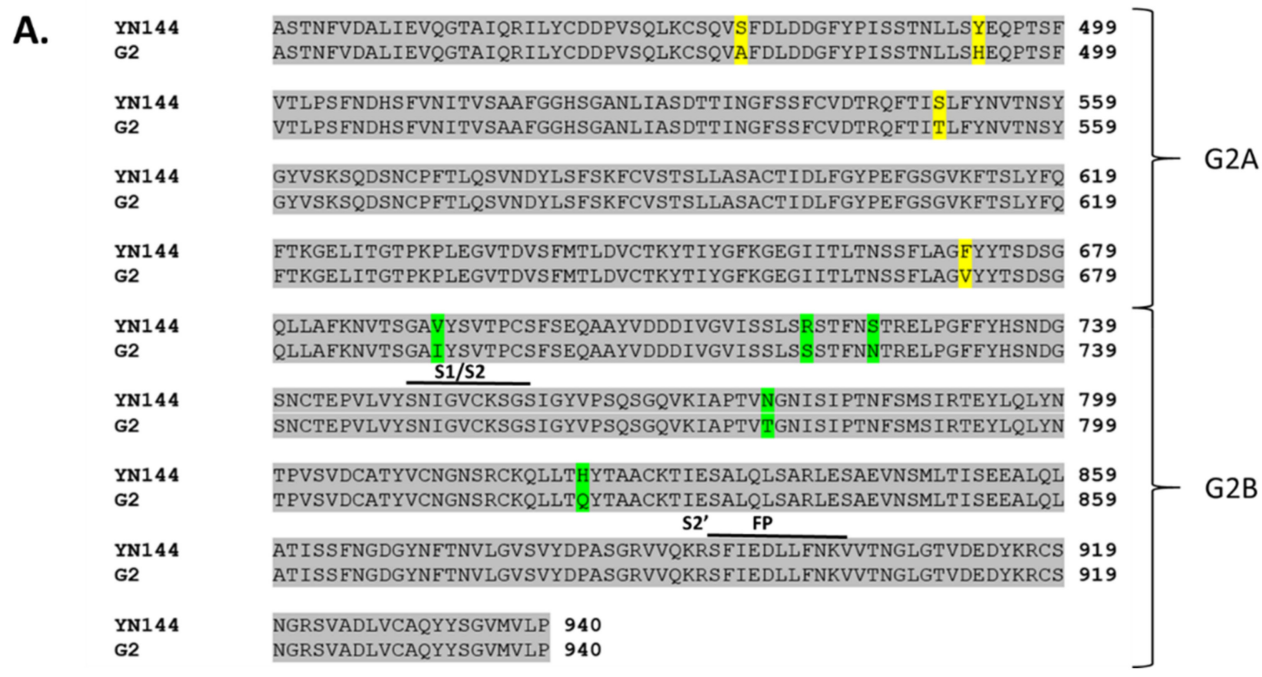

B.

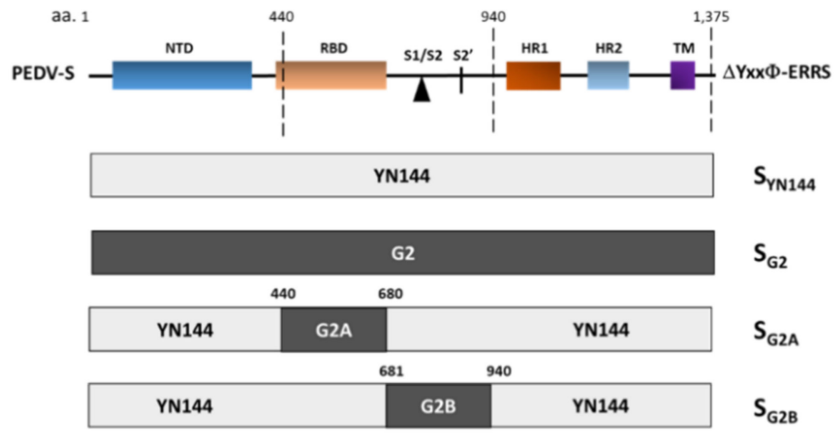

C.
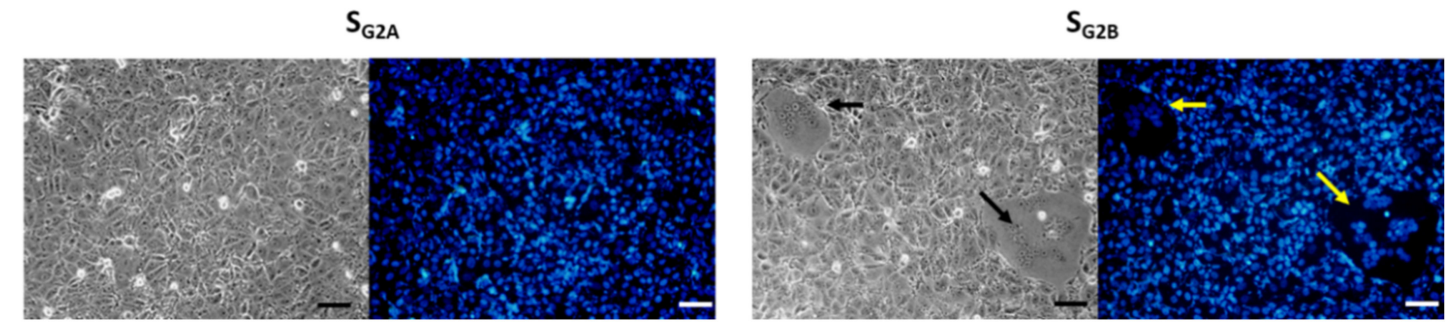

Figure 4. RBD plays a key role in the syncytium formation in VeroE6-APN cells. (A) Amino acid alignment between $\mathrm{S}_{\mathrm{YN} 144}$ and $\mathrm{S}_{\mathrm{G} 2}$ in the region covering the $\mathrm{RBD}$ and $\mathrm{S} 1 / \mathrm{S} 2$ cleavage site. Colored residues are those that are different between the two strains. (B) Schematic representation of chimeric PEDV $S$ in which the RBD or the S1/S2 cleavage site of $S_{\mathrm{YN} 144}$ was replaced with that of $\mathrm{S}_{\mathrm{G} 2}$. (C) VeroE6-APN cells were transfected with pCAGGS expressing the chimeric $\mathrm{S}_{\mathrm{G} 2 \mathrm{~A}}$ and $\mathrm{S}_{\mathrm{G} 2 \mathrm{~B}}$ and cultured in the presence of trypsin. At $24 \mathrm{hpt}$, cells were evaluated for syncytium formation. Hoechst was used to stain nuclei. Arrows denote the formation of the syncytium. Scale $50 \mu \mathrm{m}$.

We next sought to determine the effect of each amino acid in the RBD of $\mathrm{S}_{\mathrm{G} 2}$ by introducing a mutation of each amino acid in the RBD of $\mathrm{S}_{\mathrm{G} 2 \mathrm{~B}}$ (A475S, H493Y, T550S, and V672F) and assessed the presence of syncytia in cells transfected with each construct. As shown in Figure 5A, cells expressing $\mathrm{S}_{\mathrm{G} 2 \mathrm{~A}}$ carrying $\mathrm{H} 493 \mathrm{Y}$ and T550S did not display detectable syncytium formation. In contrast, those expressing $\mathrm{S}_{\mathrm{G} 2 \mathrm{~A}}$ with $\mathrm{A} 475 \mathrm{~S}$ and $\mathrm{V} 672 \mathrm{~F}$ exhibited detectable syncytia. Among all mutations, cells expressing $\mathrm{S}_{\mathrm{G} 2 \mathrm{~A}}$ with $\mathrm{V} 672 \mathrm{~F}$ mutation showed remarkably large syncytia, suggesting that $\mathrm{F}$ at the position 672 is critical for the syncytium formation in VeroE6-APN cells. Furthermore, when cells 
expressing $\mathrm{S}_{\mathrm{G} 2 \mathrm{~A}}$ carrying double mutations (A475S, V672F) were assessed for syncytium formation, we observed syncytia slightly larger than those with a single V672F substitution (Figure 5B). These data altogether point to the possibility that A475S might synergize with V672F in promoting cell-cell fusion. To investigate the importance of the $\mathrm{F} 672$ residue, we introduced a single V672F substitution to $\mathrm{S}_{\mathrm{G} 2}\left(\mathrm{~S}_{\mathrm{G} 2-\mathrm{V} 672 \mathrm{~F}}\right)$ and evaluated its ability to induce cell-cell fusion. While the wild-type $\mathrm{S}_{\mathrm{G} 2}$ could not trigger detectable syncytium in transfected cells, we could detect large syncytia in VeroE6-APN cells expressing $\mathrm{S}_{\mathrm{G} 2-\mathrm{V} 672 \mathrm{~F}}$ (Figure 5B). Notably, cells expressing $\mathrm{S}_{\mathrm{G} 2}$ with a single A475S mutation $\left(\mathrm{S}_{\mathrm{G} 2-\mathrm{A} 475 \mathrm{~S}}\right)$ did not show detectable syncytium formation. However, when double mutations (A475S, V672F) were introduced, large syncytia were observed (Figure 5C). It is also important to note that syncytia in $\mathrm{S}_{\mathrm{G} 2-\mathrm{V} 672 \mathrm{~F}^{-}}$-transfected cells were smaller than those transfected with $\mathrm{S}_{\mathrm{G} 2 \mathrm{~A}-\mathrm{V} 672 \mathrm{~F}}$ (Figure 5B), thereby further supporting the notion that other amino acids in the $\mathrm{S}_{\mathrm{YN} 144}$ might work in concert with V672F to drive the optimal cell-cell fusion.

A.

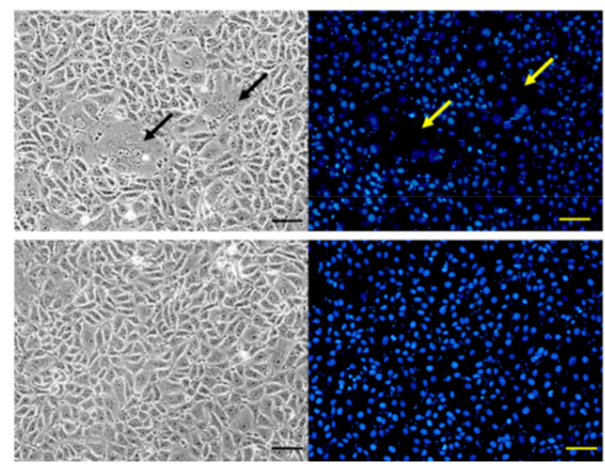

A475S

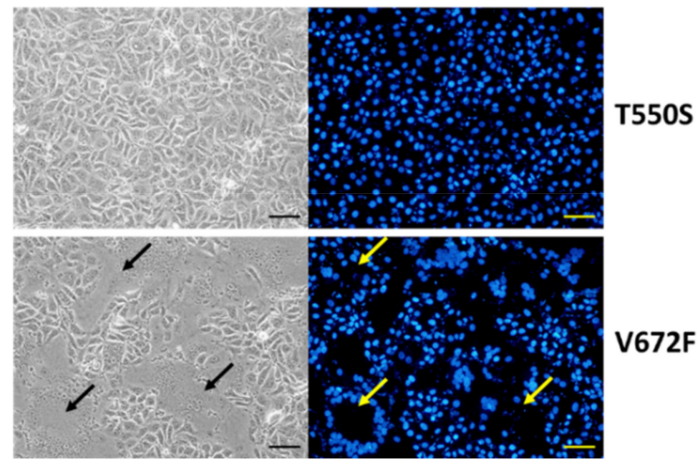

B.
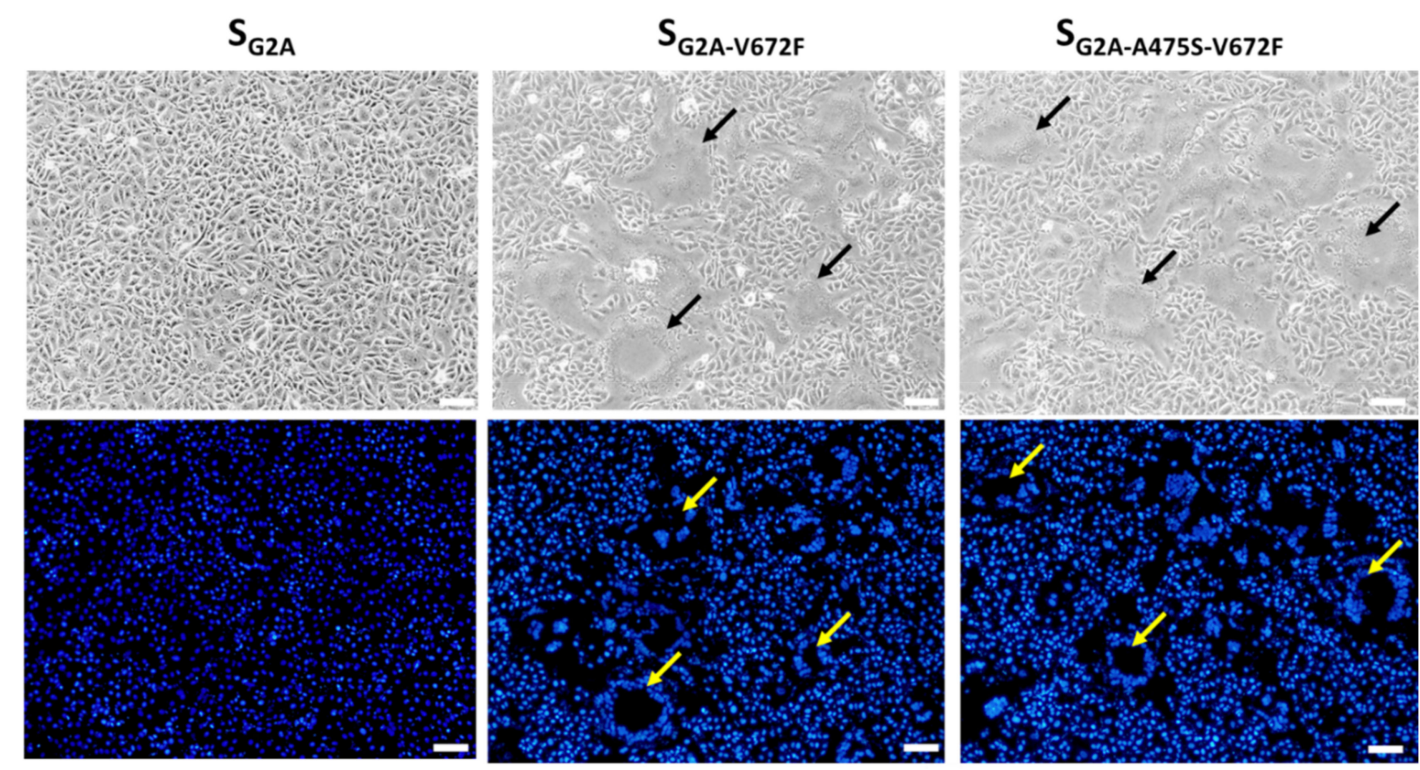

Figure 5. Cont. 
C.
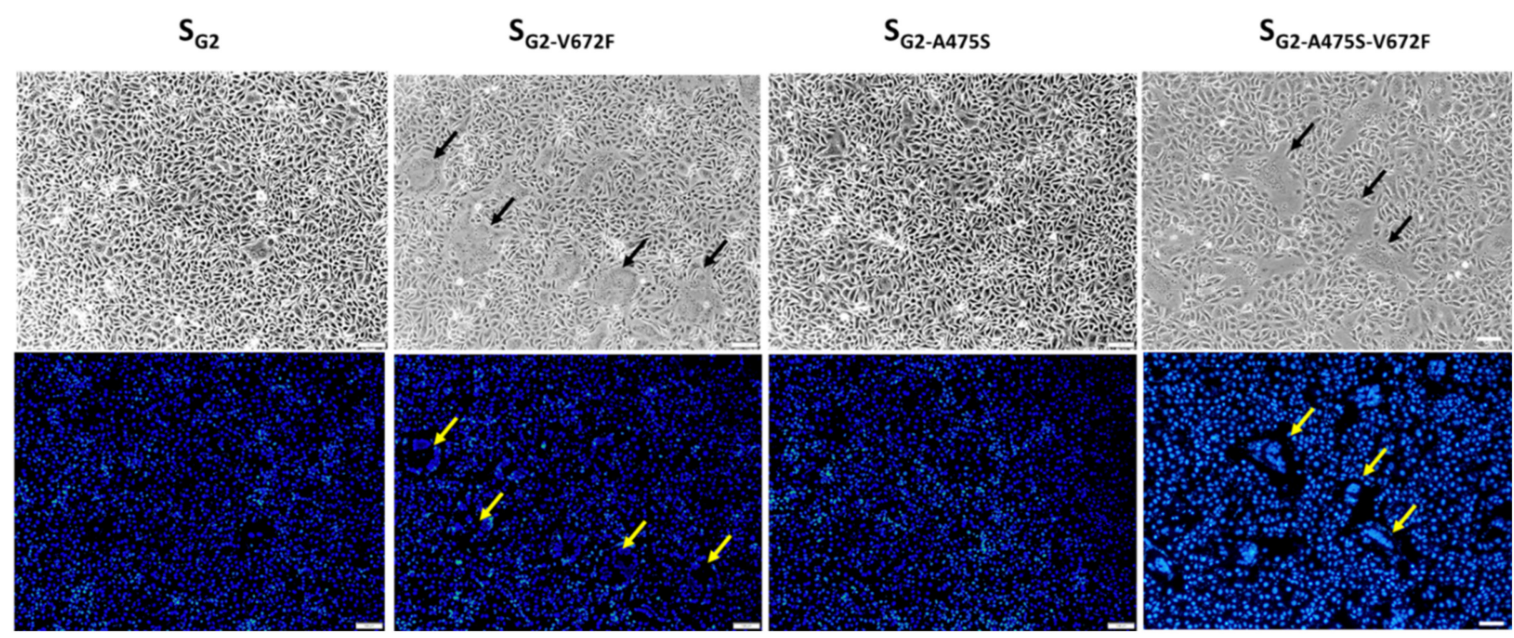

Figure 5. Effect of amino acid substitution in the RBD of $\mathrm{S}_{\mathrm{G} 2}$ on syncytium formation in VeroE6-APN cells. (A) VeroE6-APN cells were transfected with pCAGGS expressing $\mathrm{S}_{\mathrm{G} 2 \mathrm{~A}}$ with single amino acid substitution at positions 475, 493, 550, and 672 and treated with trypsin. At $24 \mathrm{hpt}$, cells were assessed for syncytium formation. Scale $50 \mu \mathrm{m}$. (B) VeroE6-APN cells were transfected with pCAGGS expressing $\mathrm{S}_{\mathrm{G} 2 \mathrm{~A}}, \mathrm{~S}_{\mathrm{G} 2 \mathrm{~A}-\mathrm{V} 672 \mathrm{~F}}$, and $\mathrm{S}_{\mathrm{G} 2 \mathrm{~A}-\mathrm{A} 475 \mathrm{~S}-\mathrm{V} 672 \mathrm{~F}}$ and cultured in the presence of trypsin. At $24 \mathrm{hpt}$, cells were evaluated for syncytium formation. Hoechst was used to stain nuclei. Arrows denote the formation of the syncytium. Scale $100 \mu \mathrm{m}$. (C) VeroE6-APN cells were transfected with pCAGGS

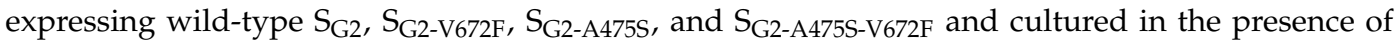
trypsin. At $24 \mathrm{hpt}$, cells were evaluated for syncytium formation. Hoechst was used to stain nuclei. Arrows denote the formation of the syncytium. Scale $100 \mu \mathrm{m}$.

\subsection{The Effect of the V672F Substitution Is Specific for VeroE6 Cells}

The fact that residues in the RBD are critical for cell-cell fusion strongly suggests that the interaction of $S$ and the receptor is critical for the process. While porcine aminopeptidase $N$ (pAPN) was initially identified as a natural receptor of PEDV [20-22], several recent studies demonstrated that neither the overexpression, nor the complete knockout of APN affects PEDV infectivity in cultured cells [23-25]. Since our results were based on the transfection of plasmids in VeroE6-APN cells, we asked whether the expression of chimeric $S$ in the parental VeroE6 cells would result in syncytium formation in a similar manner. To this end, we transfected pCAGGS expressing $S$ of various constructs into parental VeroE6 cells and examined the syncytium formation. As shown in Figure 6, similar to what was observed in VeroE6-APN cells (Figures 4 and 5), VeroE6 cells displayed large syncytium

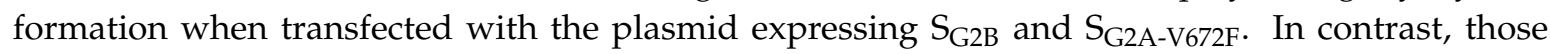
transfected with the plasmid expressing $\mathrm{S}_{\mathrm{G} 2 \mathrm{~A}}$ showed undetectable syncytium formation. These data suggest that PEDV S likely binds to the receptor present in both VeroE6 and VeroE6-APN cells.

It is currently unknown how PEDV initiates its entry into Vero or VeroE6 cells. The receptor residing on the VeroE6 cell surface also remains to be identified. Indeed, the fact that the V672F substitution could enhance S-mediated cell-cell fusion in VeroE6 cells points to the possibility that this residue might be important for the interaction of $S$ and its receptor. To test whether $V 672 \mathrm{~F}$ is specific for the receptor of VeroE6 cells, we transfected VeroE6 and Huh-7 cells with plasmids expressing various constructs of $S$ and compared syncytium formation in both cell lines. To our surprise, large syncytia could be detected in Huh-7 cells transfected with all chimeric $S$ constructs including the $S_{\mathrm{G} 2 \mathrm{~A}}$ that could not trigger cell-cell fusion in VeroE6 cells (Figure 7). Interestingly, we also found syncytium formation in Huh-7 cells transfected with pCAGGS expressing $\mathrm{S}_{\mathrm{G} 2}$. These results suggest that the mode of binding between $S$ and receptors on VeroE6 cells may be different from that of Huh-7 cells. 

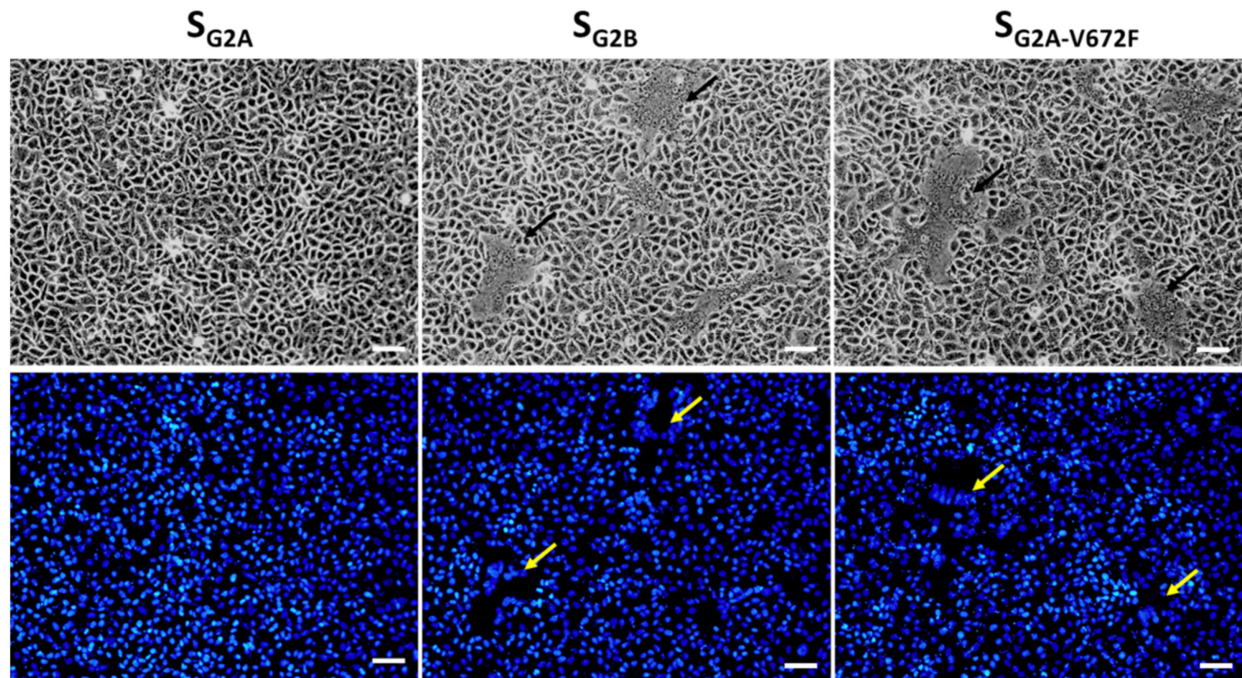

Figure 6. Syncytium formation in VeroE6 cells expressing PEDV S. VeroE6 cells were transfected with pCAGGS expressing $\mathrm{S}_{\mathrm{G} 2 \mathrm{~A}}, \mathrm{~S}_{\mathrm{G} 2 \mathrm{~B}}$, and $\mathrm{S}_{\mathrm{G} 2 \mathrm{~A}-\mathrm{V} 672 \mathrm{~F}}$ and treated with trypsin. At $24 \mathrm{hpt}$, cells were assessed for syncytium formation. Hoechst was used to stain nuclei. Arrows denote the formation of the syncytium. Scale $50 \mu \mathrm{m}$.

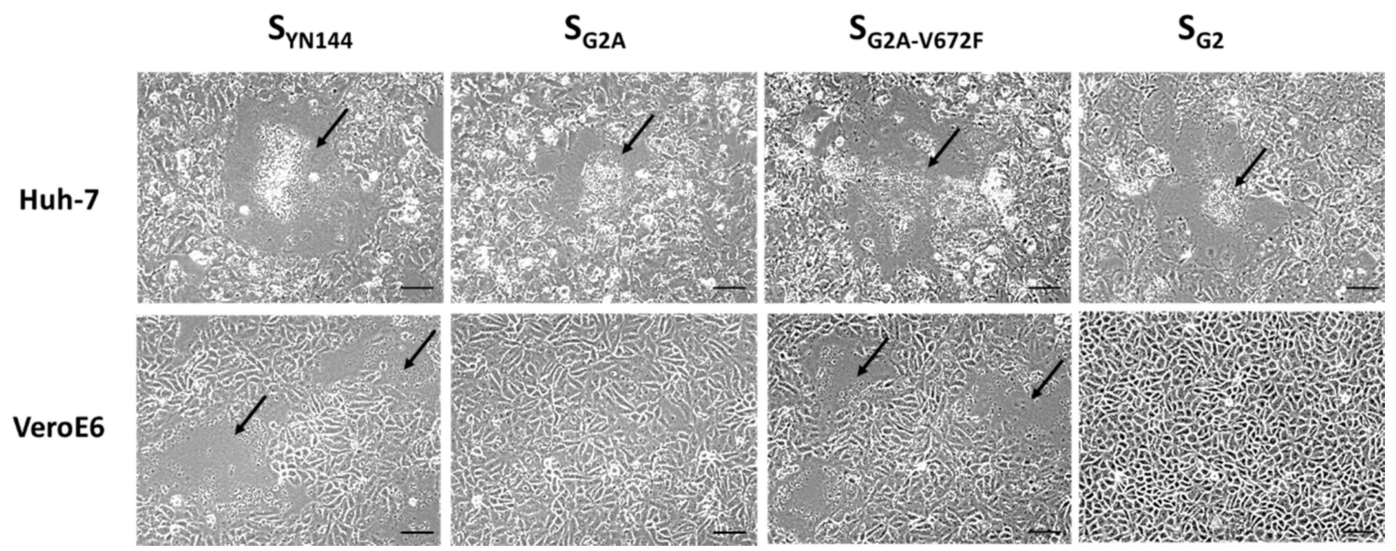

Figure 7. Syncytium formation in Huh-7 and VeroE6 cells expressing PEDV S. Huh-7 and VeroE6 cells

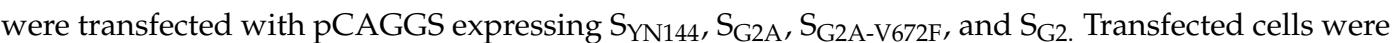
cultured in the presence of trypsin. At $24 \mathrm{hpt}$, cells were examined for syncytium formation. Arrows denote the formation of the syncytium. Scale $50 \mu \mathrm{m}$.

\subsection{Effect of the V672F Substitution on the Recombinant PEDV Growth}

To assess the effect of the V672F substitution in the virus infection context, we modified the infectious clone of PEDV $\mathrm{AVCT12}_{2}$ carrying the mCherry gene (rgPEDV-AVCT12mCherry) [13] by swapping the original $\mathrm{S}$ with $\mathrm{S}_{\mathrm{G} 2}$ and with that harboring the V672F mutation (Figure 8A). We subsequently rescued the viruses and assessed their growth in VeroE6-APN and Huh-7 cells. As expected, while PEDV with the wild-type $\mathrm{S}_{\mathrm{G} 2}$ grew poorly with undetectable syncytia (data not shown), the virus carrying the V672F mutation showed clear syncytium formation during the first passage in VeroE6-APN cells (Figure 8B). The replication kinetics of the recombinant virus also correlated with the ability to form syncytia in infected cells (Figure 8C). Notably, both recombinant viruses could grow in Huh-7 cells with comparable growth kinetics (Figure 8C). Interestingly, the recombinant virus bearing $\mathrm{S}_{\mathrm{YN} 144}$ with $\mathrm{F} 672 \mathrm{~V}$ exhibited significantly slower growth kinetics when compared to those with the wild-type $\mathrm{S}_{\mathrm{YN} 144}$ in VeroE6-APN but not in Huh-7 cells (Figure 8C). Taken together, these data suggest that $\mathrm{V} 672 \mathrm{~F}$ could enable $\mathrm{S}_{\mathrm{G} 2}$ to possibly bind to its receptor, undergo cell-cell fusion, and initiate replication in VeroE6-APN cells. 
A.

\begin{tabular}{|c|c|c|c|c|c|c|c|c|}
\hline Rep 1a & Rep 1b & $\mathrm{S}_{\mathrm{G} 2}$ & mon & E & M & $\mathbf{N}$ & AAA & rgPEDV-AVCT12mcherry- $\mathrm{S}_{\mathrm{G} 2}$ \\
\hline Rep 1a & Rep $1 b$ & $S_{G 2-V 672 F}$ & $\mathrm{mch}$ & E & $M$ & $\mathbf{N}$ & AAA & rgPEDV-AVCT $12 m$ cherry-S $S_{\mathrm{G} 2 \mathrm{~V}-\mathrm{v} 672 \mathrm{~F}}$ \\
\hline
\end{tabular}

B.
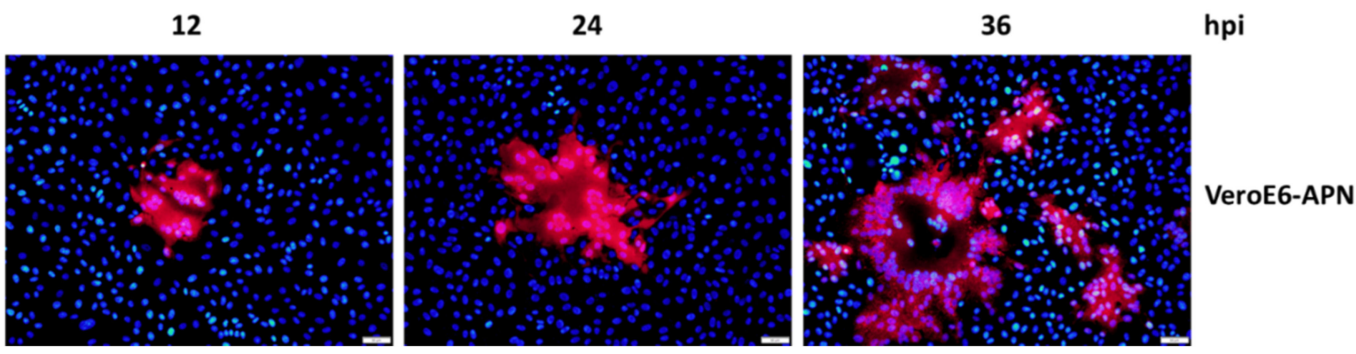

C.

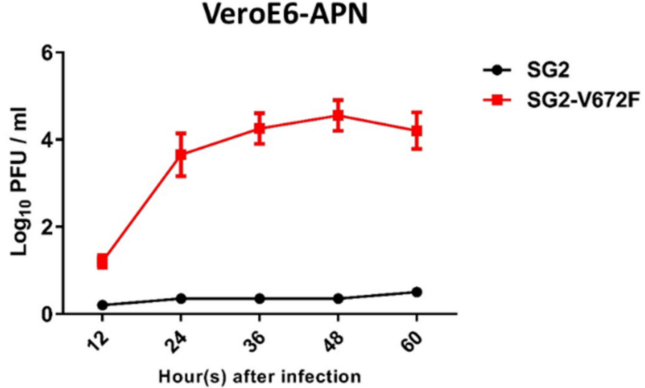

VeroE6-APN

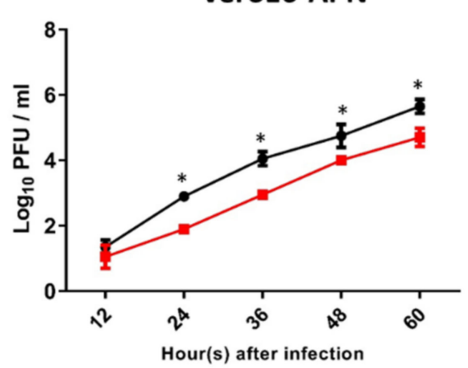

Huh-7

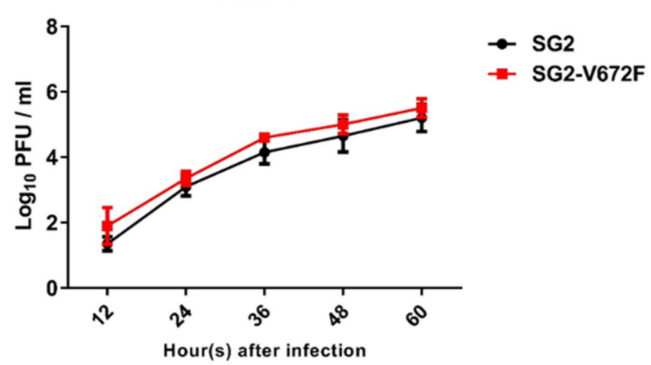

Huh-7

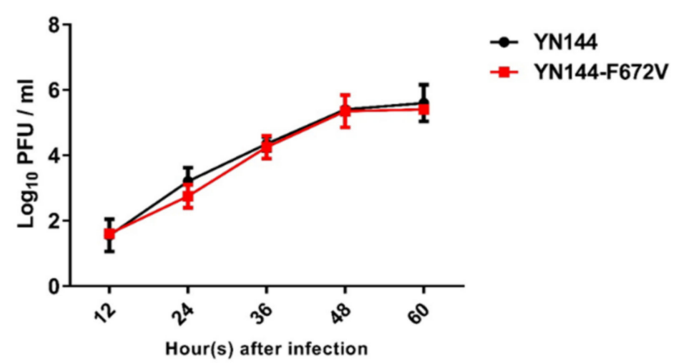

Figure 8. Effect of the V672F substitution on the growth of PEDV in VeroE6-APN cells. (A) Schematic representation of infectious clones used for generation of recombinant PEDV bearing $\mathrm{S}_{\mathrm{G} 2}$ or $\mathrm{S}_{\mathrm{G} 2-\mathrm{V} 672 \mathrm{~F}}$. (B) VeroE6-APN cells were adsorbed with supernatants harvested from HEK293T cells transfected with the infectious clone of rgPEDV-AVCT12mCherry-S $\mathrm{G}_{\mathrm{G} 2 \mathrm{~V} 672 \mathrm{~F}}$. The expression of mCherry was assessed by fluorescence microscopy at indicated times after adsorption. Scale $50 \mu \mathrm{m}$. (C) Growth kinetics of recombinant PEDV bearing $\mathrm{S}_{\mathrm{G} 2}, \mathrm{~S}_{\mathrm{G} 2-\mathrm{V} 672 \mathrm{~F}}, \mathrm{~S}_{\mathrm{YN} 144}$, and $\mathrm{S}_{\mathrm{YN} 144}$ with F672V substitution in VeroE6-APN and Huh-7 cells. Error bars represent mean $\pm \mathrm{SD}$. ${ }^{*} p<0.05$.

\section{Discussion}

In vitro propagation of the field-isolated PEDV has been a technical challenge since the virus was first isolated decades ago [26]. Through multiple passaging in cultured cells, cell-adapted PEDV strains could occasionally be obtained. Although cells infected by cell-adapted PEDV usually display extensive syncytia, those infected by early passaged PEDV strains or in vivo exhibit minimal, if not undetectable, syncytium formation. While it is clear that changes in the $S$ protein accumulated during consecutive passages in Vero cells are associated with the ability of $S$ to induce large syncytium formation, the mechanism by which these mutations in the S protein affect the cell-cell fusion and virus growth in the host cells is still not well understood. In this study, we investigated the ability of 
PEDV S to induce syncytium formation in VeroE6 cells using those that derived from a field isolate (G2) and a cell-adapted variant (YN144).

The syncytium formation is usually triggered as a result of the binding between $S$ on the infected cells' surface and its receptor on adjacent cells. However, it is not clear how S, especially of cell-adapted strains, could transit to the plasma membrane as its cellular localization is known to be tightly regulated by the C-terminal motifs [5]. A few cell-adapted strains in the GI genogroup such as SM98, AVCT12, or CHM2013 or GII genogroup such as FL2013 could form large syncytia in infected cells mainly due to the natural C-terminal deletion of the $S$ gene $[13,27,28]$. Interestingly, Vero cells infected with some cell-adapted strains, such as YN144 [12], PT-P96 [29], or KNU-141112 [30], could exhibit large syncytia even though the viruses still possess the intact C-terminal motifs. We showed here that $\mathrm{S}_{\mathrm{YN} 144}$ displayed hardly detectable cell surface expression, while $\mathrm{S}_{\mathrm{YN} 144 \Delta E R R S}$ showed strong surface expression in transfected cells (Figure 2A). These data thus suggest that a minute amount of the $S$ protein on the cell surface might be sufficient for the induction of syncytium formation. It is also important to note that $\mathrm{S}_{\mathrm{G} 2 \triangle \mathrm{ERRS}}$, though it displayed strong surface expression, could not form detectable syncytium in VeroE6-APN cells (Figure 2A), which further supports the notion that the surface expression is not sufficient for promoting syncytium formation in cells expressing PEDV S.

In addition, results from this study lead us to speculate that regions outside the C-terminal motifs might play a role in the S-mediated formation of syncytium in VeroE6 cells. Syncytium formation in cells expressing various chimeric $S$ constructs indeed revealed that the RBD of SYN144, $_{\text {, but not the S1/S2 }}$ junction or fusion peptide cleavage site, might be critical for the cell-cell fusion in VeroE6-APN cells. Specifically, a single amino acid substitution at position 672 in the RBD from valine to phenylalanine (V672F) could render PEDV S of a typical field isolate to mediate cell-cell fusion in VeroE6-APN cells. Moreover, the recombinant PEDV bearing $\mathrm{S}_{\mathrm{G} 2}$ with $\mathrm{V} 672 \mathrm{~F}$ mutation also replicated efficiently in VeroE6-APN cells, while that harboring the wild-type $\mathrm{S}_{\mathrm{G} 2}$ grew poorly, thereby supporting the notion that the syncytium formation is likely associated with the high-growth characteristic of PEDV. It should be emphasized, however, that V672F was specific for syncytium induction in VeroE6 or VeroE6-APN cells. We showed that $\mathrm{SY}_{\mathrm{N} 144}$ carrying the RBD derived from $\mathrm{S}_{\mathrm{G} 2}$ could effectively induce syncytium in Huh-7, but not in VeroE6-APN cells. This finding thus points to the possibility that $S$ might interact with different receptors on Huh-7 and VeroE6-APN cells. Given that pAPN has been recently shown to be unnecessary for PEDV entry [22,23,25], the functional PEDV receptor on Huh-7 cells is unlikely to be the human APN but may instead be some other surface protein(s) that might be absent in Vero or VeroE6 cells. Another important point worth mentioning is that all recombinant viruses that grew poorly in VeroE6-APN cells could replicate efficiently in Huh-7 cells. These results suggest that Huh-7 cells might be a more suitable host for isolating and propagating field-isolated PEDV than Vero or VeroE6 cells.

Sequence analyses of PEDV S in the GenBank database revealed that the majority amino acid at the position 672 of GII PEDV S is valine (V672) with less than $5 \%$ of available data showing phenylalanine (F672) and isoleucine (I672). Interestingly, F672 is also found in an early passage of YN144, YN15 (GenBank KT021228.1), which indicates that this specific residue is unlikely to be the result of adaptive mutations that occurred during serial passages. To the best of our knowledge, V672F has never been reported specifically as a mutation in cell-adapted strains. One cell-adapted strain, so-called LZW, was reported to carry F672 at passage 24 (GenBank AIJ01341), but it is not known whether this residue was also present in the original isolate. It is notable that while several cell-adapted PEDVs have been recently characterized and reported, common mutations in $S$ that confer cell adaptation are not yet identified. For example, Zhou et al. have recently reported that A389S, P803H, Q825H, I1,010T, and C1,362G mutations in S of PEDV strain ZJ15XS0101 at passage 120 could enable the virus to replicate up to $10.125 \log 10 \mathrm{TCID} 50 / \mathrm{mL}$ in VeroE6 cells [31]. However, the same mutations were never reported in other known cell-adapted strains. We also demonstrated in this study that the recombinant virus bearing V672 showed slower growth kinetics than that with F672 in VeroE6-APN cells. It is thus 
likely that PEDV with F672 could be found in some natural isolates and these strains might be more efficiently propagated in Vero or VeroE6 cells when compared to those carrying S with V672.

In summary, using the in vitro assay to assess S-mediated cell-cell fusion and the reverse genetics of PEDV, our results altogether suggest that syncytium formation is associated with the high growth characteristic of cell-adapted PEDV. We demonstrate in this study that a single V672F substitution could render PEDV carrying $S$ derived from a poorly culturable isolate to trigger large syncytia and replicate efficiently in VeroE6 cells. Exactly how V672F substitution causes S-mediated cell-cell fusion is still not known. However, our data point to the possibility that this single mutation in the RBD might lead to a more favorable interaction between $S$ and its host cell-specific receptor. Further functional analyses are needed to elucidate the detailed mechanism of how V672F contributes to PEDV S-mediated cell-cell fusion. More importantly, the identification of the PEDV receptor on VeroE6 cells will provide further insights.

Author Contributions: Conceptualization, A.J.; investigation, methodology, and validation, A.W., J.S., C.K., and K.S.; resources, A.J.; writing—original draft preparation, A.J.; writing—review and editing, A.J. All authors read and approved the manuscript.

Acknowledgments: This work was financially supported by BIOTEC's Fellow (P-15-51261) and Giga Impact Initiative (P-16-51674) grants. We thank Qigai He (Huazhong Agricultural University) for PEDV-S antibodies.

Conflicts of Interest: The authors declare no conflict of interest.

\section{References}

1. Lee, C. Porcine epidemic diarrhea virus: An emerging and re-emerging epizootic swine virus. Virol. J. 2015, 12, 193. [CrossRef] [PubMed]

2. Jung, K.; Saif, L.J. Porcine epidemic diarrhea virus infection: Etiology, epidemiology, pathogenesis and immunoprophylaxis. Vet. J. 2015, 204, 134-143. [CrossRef]

3. Sun, J.; Li, Q.; Shao, C.; Ma, Y.; He, H.; Jiang, S.; Zhou, Y.; Wu, Y.; Ba, S.; Shi, L.; et al. Isolation and characterization of Chinese porcine epidemic diarrhea virus with novel mutations and deletions in the $S$ gene. Vet. Microbiol. 2018, 221, 81-89. [CrossRef]

4. Chen, N.; Li, S.; Zhou, R.; Zhu, M.; He, S.; Ye, M.; Huang, Y.; Li, S.; Zhu, C.; Xia, P.; et al. Two novel porcine epidemic diarrhea virus (PEDV) recombinants from a natural recombinant and distinct subtypes of PEDV variants. Virus Res. 2017, 242, 90-95. [CrossRef] [PubMed]

5. Ujike, M.; Taguchi, F. Incorporation of spike and membrane glycoproteins into coronavirus virions. Viruses 2015, 7, 1700-1725. [CrossRef]

6. Nguyen, V.P.; Hogue, B.G. Protein interactions during coronavirus assembly. J. Virol. 1997, 71, 9278-9284. [PubMed]

7. Opstelten, D.J.; Raamsman, M.J.; Wolfs, K.; Horzinek, M.C.; Rottier, P.J. Envelope glycoprotein interactions in coronavirus assembly. J. Cell Biol. 1995, 131, 339-349. [CrossRef]

8. McBride, C.E.; Li, J.; Machamer, C.E. The cytoplasmic tail of the severe acute respiratory syndrome coronavirus spike protein contains a novel endoplasmic reticulum retrieval signal that binds COPI and promotes interaction with membrane protein. J. Virol. 2007, 81, 2418-2428. [CrossRef] [PubMed]

9. Wanitchang, A.; Saenboonrueng, J.; Srisutthisamphan, K.; Jongkaewwattana, A. Characterization of influenza A virus pseudotyped with the spike protein of porcine epidemic diarrhea virus. Arch. Virol. 2018, 163, 3255-3264. [CrossRef]

10. Hou, Y.; Lin, C.M.; Yokoyama, M.; Yount, B.L.; Marthaler, D.; Douglas, A.L.; Ghimire, S.; Qin, Y.; Baric, R.S.; Saif, L.J.; et al. Deletion of a 197-Amino-Acid Region in the N-Terminal Domain of Spike Protein Attenuates Porcine Epidemic Diarrhea Virus in Piglets. J. Virol. 2017, 91. [CrossRef] [PubMed]

11. Li, Z.; Chen, F.; Ye, S.; Guo, X.; Muhanmmad Memon, A.; Wu, M.; He, Q. Comparative Proteome Analysis of Porcine Jejunum Tissues in Response to a Virulent Strain of Porcine Epidemic Diarrhea Virus and Its Attenuated Strain. Viruses 2016, 8, 323. [CrossRef]

12. Chen, F.; Zhu, Y.; Wu, M.; Ku, X.; Ye, S.; Li, Z.; Guo, X.; He, Q. Comparative Genomic Analysis of Classical and Variant Virulent Parental/Attenuated Strains of Porcine Epidemic Diarrhea Virus. Viruses 2015, 7, 5525-5538. [CrossRef] 
13. Jengarn, J.; Wongthida, P.; Wanasen, N.; Frantz, P.N.; Wanitchang, A.; Jongkaewwattana, A. Genetic manipulation of porcine epidemic diarrhoea virus recovered from a full-length infectious cDNA clone. J. Gen. Virol. 2015, 96, 2206-2218. [CrossRef]

14. Hou, Y.; Meulia, T.; Gao, X.; Saif, L.J.; Wang, Q. Deletion of both the Tyrosine-Based Endocytosis Signal and the Endoplasmic Reticulum Retrieval Signal in the Cytoplasmic Tail of Spike Protein Attenuates Porcine Epidemic Diarrhea Virus in Pigs. J. Virol. 2019, 93, e01758-18. [CrossRef]

15. Shirato, K.; Maejima, M.; Matsuyama, S.; Ujike, M.; Miyazaki, A.; Takeyama, N.; Ikeda, H.; Taguchi, F. Mutation in the cytoplasmic retrieval signal of porcine epidemic diarrhea virus spike (S) protein is responsible for enhanced fusion activity. Virus Res. 2011, 161, 188-193. [CrossRef]

16. Winter, C.; Schwegmann-Wessels, C.; Neumann, U.; Herrler, G. The spike protein of infectious bronchitis virus is retained intracellularly by a tyrosine motif. J. Virol. 2008, 82, 2765-2771. [CrossRef]

17. Lontok, E.; Corse, E.; Machamer, C.E. Intracellular targeting signals contribute to localization of coronavirus spike proteins near the virus assembly site. J. Virol. 2004, 78, 5913-5922. [CrossRef]

18. Moore, M.J.; Dorfman, T.; Li, W.; Wong, S.K.; Li, Y.; Kuhn, J.H.; Coderre, J.; Vasilieva, N.; Han, Z.; Greenough, T.C.; et al. Retroviruses pseudotyped with the severe acute respiratory syndrome coronavirus spike protein efficiently infect cells expressing angiotensin-converting enzyme 2. J. Virol. 2004, 78, 10628-10635. [CrossRef]

19. Wicht, O.; Li, W.; Willems, L.; Meuleman, T.J.; Wubbolts, R.W.; van Kuppeveld, F.J.; Rottier, P.J.; Bosch, B.J. Proteolytic activation of the porcine epidemic diarrhea coronavirus spike fusion protein by trypsin in cell culture. J. Virol. 2014, 88, 7952-7961. [CrossRef]

20. Shan, Z.; Yin, J.; Wang, Z.; Chen, P.; Li, Y.; Tang, L. Identification of the functional domain of the porcine epidemic diarrhoea virus receptor. J. Gen. Virol. 2015, 96, 2656-2660. [CrossRef]

21. Liu, C.; Tang, J.; Ma, Y.; Liang, X.; Yang, Y.; Peng, G.; Qi, Q.; Jiang, S.; Li, J.; Du, L.; et al. Receptor usage and cell entry of porcine epidemic diarrhea coronavirus. J. Virol. 2015, 89, 6121-6125. [CrossRef]

22. Li, B.X.; Ge, J.W.; Li, Y.J. Porcine aminopeptidase $\mathrm{N}$ is a functional receptor for the PEDV coronavirus. Virology 2007, 365, 166-172. [CrossRef]

23. Ji, C.M.; Wang, B.; Zhou, J.; Huang, Y.W. Aminopeptidase-N-independent entry of porcine epidemic diarrhea virus into Vero or porcine small intestine epithelial cells. Virology 2018, 517, 16-23. [CrossRef]

24. Li, W.; Luo, R.; He, Q.; van Kuppeveld, F.J.M.; Rottier, P.J.M.; Bosch, B.J. Aminopeptidase N is not required for porcine epidemic diarrhea virus cell entry. Virus Res. 2017, 235, 6-13. [CrossRef]

25. Shirato, K.; Maejima, M.; Islam, M.T.; Miyazaki, A.; Kawase, M.; Matsuyama, S.; Taguchi, F. Porcine aminopeptidase $\mathrm{N}$ is not a cellular receptor of porcine epidemic diarrhea virus, but promotes its infectivity via aminopeptidase activity. J. Gen. Virol. 2016, 97, 2528-2539. [CrossRef]

26. Hofmann, M.; Wyler, R. Propagation of the virus of porcine epidemic diarrhea in cell culture. J. Clin. Microbiol. 1988, 26, 2235-2239.

27. Li, J.; Jin, Z.; Gao, Y.; Zhou, L.; Ge, X.; Guo, X.; Han, J.; Yang, H. Development of the full-length cDNA clones of two porcine epidemic diarrhea disease virus isolates with different virulence. PLoS ONE 2017, 12, e0173998. [CrossRef]

28. Zhang, X.; Pan, Y.; Wang, D.; Tian, X.; Song, Y.; Cao, Y. Identification and pathogenicity of a variant porcine epidemic diarrhea virus field strain with reduced virulence. Virol. J. 2015, 12, 88. [CrossRef]

29. Kao, C.F.; Chiou, H.Y.; Chang, Y.C.; Hsueh, C.S.; Jeng, C.R.; Tsai, P.S.; Cheng, I.C.; Pang, V.F.; Chang, H.W. The Characterization of Immunoprotection Induced by a cDNA Clone Derived from the Attenuated Taiwan Porcine Epidemic Diarrhea Virus Pintung 52 Strain. Viruses 2018, 10, 543. [CrossRef]

30. Lee, S.; Kim, Y.; Lee, C. Isolation and characterization of a Korean porcine epidemic diarrhea virus strain KNU-141112. Virus Res. 2015, 208, 215-224. [CrossRef]

31. Zhou, Y.; Chen, C.; Chen, Y.; Liu, Z.; Zheng, J.; Wang, T.; Luo, H.; Liu, Y.; Shan, Y.; Fang, W.; et al. Effect of route of inoculation on innate and adaptive immune responses to porcine epidemic diarrhea virus infection in suckling pigs. Vet. Microbiol. 2019, 228, 83-92. [CrossRef] [PubMed]

(C) 2019 by the authors. Licensee MDPI, Basel, Switzerland. This article is an open access article distributed under the terms and conditions of the Creative Commons Attribution (CC BY) license (http://creativecommons.org/licenses/by/4.0/). 